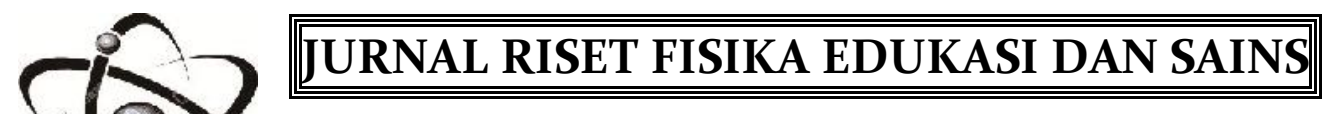

Education and Science Physics Journal

E- ISSN : 2503-3425

P- ISSN : 2407-3563

JRFES Vol 1, No 2 (2015) 53-60

http://ejournal.stkip-pgri-sumbar.ac.id/index.php/JRFES

\title{
PENGEMBANGAN MODUL PRAKTIKUM BERNUANSA KONTEKSTUAL PADA MATERI EKSPERIMEN FISIKA DI STKIP PGRI SUMATERA BARAT
}

\author{
Zulpadrianto $^{1}$ Husna $^{2}$ \\ ${ }^{1,2}$ Pendidikan fisika, STKIP PGRI Sumatera Barat \\ Email: zpadrianto@gmail.com \\ http://dx.doi.org/10.22202/jrfes.2015.v1i2.1402
}

\begin{abstract}
Improving the quality of teaching needs to be earned by teachers in learning activities. One effort to improve the quality of education is the development of experimental module that isattractive and easy to understand. This type of research is the development of researchusingthree stages: define, design and develop. Define phase is the phase of analysis and formulationof learning objectives physics experiments. At the design stage to design modules contextualnuances. At this stage of develop validated module by 5 people validator and test the practicalities by 2 faculty members, 20 students of physical education. This research data is primary data obtained from the questionnaire validity and practicalities. Data were analyzed with descriptive analysis using a percentage formula. From this research, produced a nuanced physics experiment lab module contextual validity of results obtained value of $88.17 \%$ with a valid criteria. Average of practicallity value $90.83 \%$ with a very practical criterion, while the practicalities of Student test results have an average value of $84.09 \%$ with a practical criterion It can be concluded that the modules developed to have a valid and practical criteria.
\end{abstract} Key Word: Practical guide, Contextual

\begin{abstract}
Abstrak
Peningkatan kualitas pengajaran perlu diupayakan oleh pengajar dalam kegiatan pembelajaran. Salah satu upaya untuk peningkatan kualitas pendidikan berupa pengembangan modul praktikum yang menarik dan mudah dipahami. Jenis penelitian ini adalah penelitian pengembangan menggunakan 3 tahap yaitu define, design and develop. Tahap define merupakan tahap analisis dan perumusan tujuan pembelajaran eksperimen fisika. Pada tahap design dilakukan perancangan modul bernuansa kontekstual. Pada tahap develop dilakukan validasi modul oleh 5 orang validator dan uji praktikalitas oleh 2 orang tenaga pengajar, 20 orang mahasiswa program studi pendidikan fisika. Data penelitian ini adalah data primer yang diperoleh dari angket validitas dan praktikalitas. Data dianalisis dengan analisis deskriptif menggunakan rumus persentase. Dari penelitian ini, dihasilkan modul praktikum eksperimen fisika bernuansa kontekstual Hasil validitas diperoleh nilai sebesar $88,17 \%$ dengan kriteria valid. Nilai praktikalitasnyai rata-rata 90,83\% dengan kriteria sangat praktis, sedangkan hasil uji praktikalitas oleh mahasiswa memiliki nilai rata-rata 84,09\% dengan kriteria praktis Dengan demikian dapat disimpulkan bahwa modul yang dikembangkan memiliki kriteria yang valid dan praktis.
\end{abstract}

Kata kunci : Modul Praktikum, Kontekstual

\section{PENDAHULUAN}

Pendidikan senantiasa menjadi
perhatian utama dalam rangka


mencerdaskan kehidupan bangsa yang dalam prosesnya menuntut pengembangan potensi peserta didik secara optimal. Pendidikan mengantarkan peserta didik dalam pengalaman belajar yang bertahap dan berkelanjutan dimana setiap saat terjadi perkembangan-perkembangan baru sebagai upaya peningkatan kualitas pelaksanaannya. Peningkatan ini dapat dalam bentuk metode penyampaian materi pembelajaran, pengembangan kurikulum, serta pengembangan media pembelajaran.

Media pembelajaran dapat menjadi salah satu sumber belajar yang meningkatkan kualitas proses belajarmengajar. Susilana dan Riyana menyatakan penggunaan media pembelajaran secara kreatif akan memperbesar kemungkinan bagi pelajar untuk belajar lebih banyak dan mencamkan apa yang dipelajarinya lebih baik sesuai dengan apa yang menjadi tujuan pembelajaran. Pencapaian tujuan pembelajaran dapat terjadi karena adanya peranan media yang dikembangkan. Media pembelajaran yang dirancang secara baik akan sangat membantu peserta didik mencapai tujuan pembelajaran.

Mengembangkan media pembelajaran perlu dilakukan tenaga pengajar sebagai tenaga profesional. Salah satu keterampilan dasar yang harus dimiliki oleh seorang pengajar adalah keterampilan mengembangkan dan menggunakan media pembelajaran $^{[3]}$. Media pembelajaran yang dapat dikembangkan oleh pengajar salah satunya adalah modul tertulis. Modul tertulis merupakan media pembelajaran dalam bentuk bahan cetak, yang dapat berupa buku teks, dan modul. Depdiknas ${ }^{[3]}$ menyatakan manfaat yang dapat diperoleh apabila pengajar mengembangkan modul sendiri antara lain, akan diperoleh modul yang sesuai tuntutan kurikulum dan sesuai dengan kebutuhan peserta didik.

Berdasarkan pengamatan penulis selama membimbing praktikum di STKIP PGRI Sumatera Barat, diketahui mahasiswa telah menggunakan modul yang dibuat oleh pengajar. Namun, modul tersebut masih memiliki kelemahan, diantaranya, kurang menyajikan gambar, berisikan materi yang sulit dipahami mahasiswa karena hanya memaparkan materi tanpa mengaitkan dengan situasi dunia nyata, dan belum menggunakan bahasa yang interaktif.

Modul merupakan media cetak tertulis yang dapat disiapkan oleh pengajar untuk menuntun mahasiswa memahami materi pelajaran, dan meningkatkan motivasi mahasiswa dalam belajar. Hal ini terjadi karena modul memiliki beberapa keunggulan. Ada beberapa keunggulan modul, diantaranya mahasiswa dapat mengikuti urutan pikiran secara logis, memperlancar pemahaman informasi yang disampaikan dan mudah terdistribusi ${ }^{[5]}$.

Modul dapat membantu proses pembelajaran, sehingga bisa digunakan pengajar untuk membantu mahasiswa mencapai tujuan pembelajaran. Sebagai modul yang ekonomis dan praktis, modul berisi pokok-pokok materi yang dijabarkan lebih ringkas dan terarah, sehingga modul bukanlah bahan ajar yang memiliki ketebalan berlebihan. Menurut Susilana dan Riyana ${ }^{[1]}$ bahwa bahan ajar cetak yang tebal dapat membosankan dan mematikan minat pelajar untuk membacanya. Sejalan dengan yang diungkapkan Ahmadi dan Supriyono ${ }^{[6]}$ bahwa bahan ajar yang terlalu panjang atau terlalu banyak dapat menyebabkan kesulitan dalam belajar, karena berhubungan dengan faktor kelelahan serta kejemuan si pelajar dalam mengahadapi atau 
mengerjakan bahan yang banyak tersebut.

Modul disajikan bertujuan untuk menarik perhatian mahasiswa untuk membacanya karena modul disajikan dalam susunan teks dan gambar agar lebih mudah dipahami.

\section{METODE}

Penelitian ini adalah penelitian pengembangan (Development Research). Produk yang dikembangkan adalah modul bernuansa kontekstual dengan materi eksperimen fisika di TKIP PGRI Sumatera Barat.

Pengembangan modul dilakukan di Program Studi pendidikan Fisika STKIP PGRI SUMBAR dari bulan Agustus 2015 sampai bulan januari 2016.

Subjek penelitian ini adalah 20 orang mahasiwa pendidikan fisika yang mengambil mata kuliah eksperimen fisika, 5 orang validator yang ahli di bidangnya. Sedangkan objek penelitian ini adalah bahan ajar berupa modul bernuansa kontekstual.

Modul bernuansa kontekstual pada materi eksperimen fisika ini dikembangkan dengan menggunakan four-D-models yaitu melalui tahap define (pedefinisian), design (perancangan), develope (pengembangan), dan disseminate (penyebaran) sebagaimana yang disarankan Thiagarajan, Semmel, dan Semmel Penelitian ini dilakukan sampai development ( pengembangan).

\section{Tahap define (pendefinisian)}

Pada tahap define dilakukan penetapan dan pendefinisian syaratsyarat pembelajaran dengan menganalisis Standar Kompetensi dan bahan materi pembelajaran. Langkahlangkah pada tahap define ini meliputi; a. Analisis kebutuhan

Analisis kebutuhan bertujuan memunculkan dan menetapkan masalah dasar dalam praktikum eksperimen fisika sehingga perlu dikembangkan modul eksperimen fisika.

b. Analisis media

$\begin{array}{ccr}\text { Pada analisis } & \text { media } \\ \text { dipertimbangkan } & \text { sejauh mana }\end{array}$ media yang digunakan dalam praktikum khususnya mata kuliah eksperimen fisika dapat menarik minat, pemahaman, dan hasil belajar.

c. Analisis peserta didik

Analisis peserta didik dilakukan untuk mengetahui karakteristik peserta didik yang meliputi usia, kemampuan akademik, dan pengalaman. Dengan mengetahui dan memahami karakteristik yang dimiliki peserta didik, maka akan memudahkan merancang modul praktikum yang sesuai dengan karakteristik peserta didik sehingga dihasilkan modul yang cocok digunakan.

d. Analisis tugas

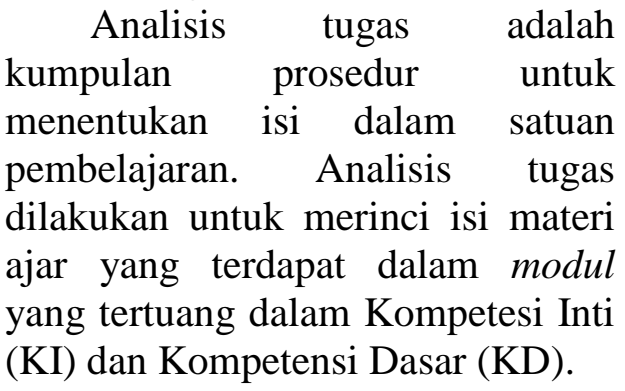

2. Tahap design (perancangan)

Tujuan tahap ini adalah untuk menyiapkan materi pembelajaran handout biologi bernuansa kontekstual dengan tampilan majalah pada materi sistem gerak pada manusia berdasarkan $\mathrm{KI}$, KD, dan indikator sesuai Kurikulum 2013. Pada tahap perancangan ini, terlebih dahulu disusun kerangka handout dengan tidak mengabaikan prinsip-prinsip 
penyusunan handout. Materi yang disajikan sesuai dengan KI, KD, dan indikator. Dalam hal ini, disisipkan nuansa kontekstual yang sesuai dengan materi pembelajaran dan disajikan dalam bentuk handout. Handout yang dirancang mengandung semua komponen handout seperti lembaran konsep-konsep, prinsip, dan gagasan pokok tentang suatu topik yang akan dibahas.

\section{Tahap develop (pengembangan)}

Tujuan dari tahap ini adalah untuk menghasilkan modul bernuansa kontekstual sudah direvisi berdasarkan masukan dari para validator.

Secara keseluruhan langkahlangkah pengembangan handout mengikuti prosedur penelitian four-D-models yang sudah dimodifikasi yang dapat diringkas seperti pada Gambar 1.

Jenis data dalam penelitian ini berupa data primer. Data yang diperoleh langsung dari lembar validitas dan praktikalitas terhadap modul. Data validitas diperoleh setelah dilakukan validasi oleh validator dan data praktikalitas didapat dari hasil uji coba modul pada praktikalitas melalui angket.

Angket uji validitas dan praktikalitas disusun menurut skala likert yang dengan 4 alternatif jawaban sebagai berikut:

$\begin{aligned} \mathrm{SS} & =\text { sangat setuju dengan bobot } 4 \\ \mathrm{~S} & =\text { setuju dengan bobot } 3 \\ \mathrm{TS} & =\text { tidak setuju dengan bobot } 2 \\ \mathrm{STS} & = \\ & \text { sangat tidak setuju dengan } \\ & \text { bobot } 1\end{aligned}$

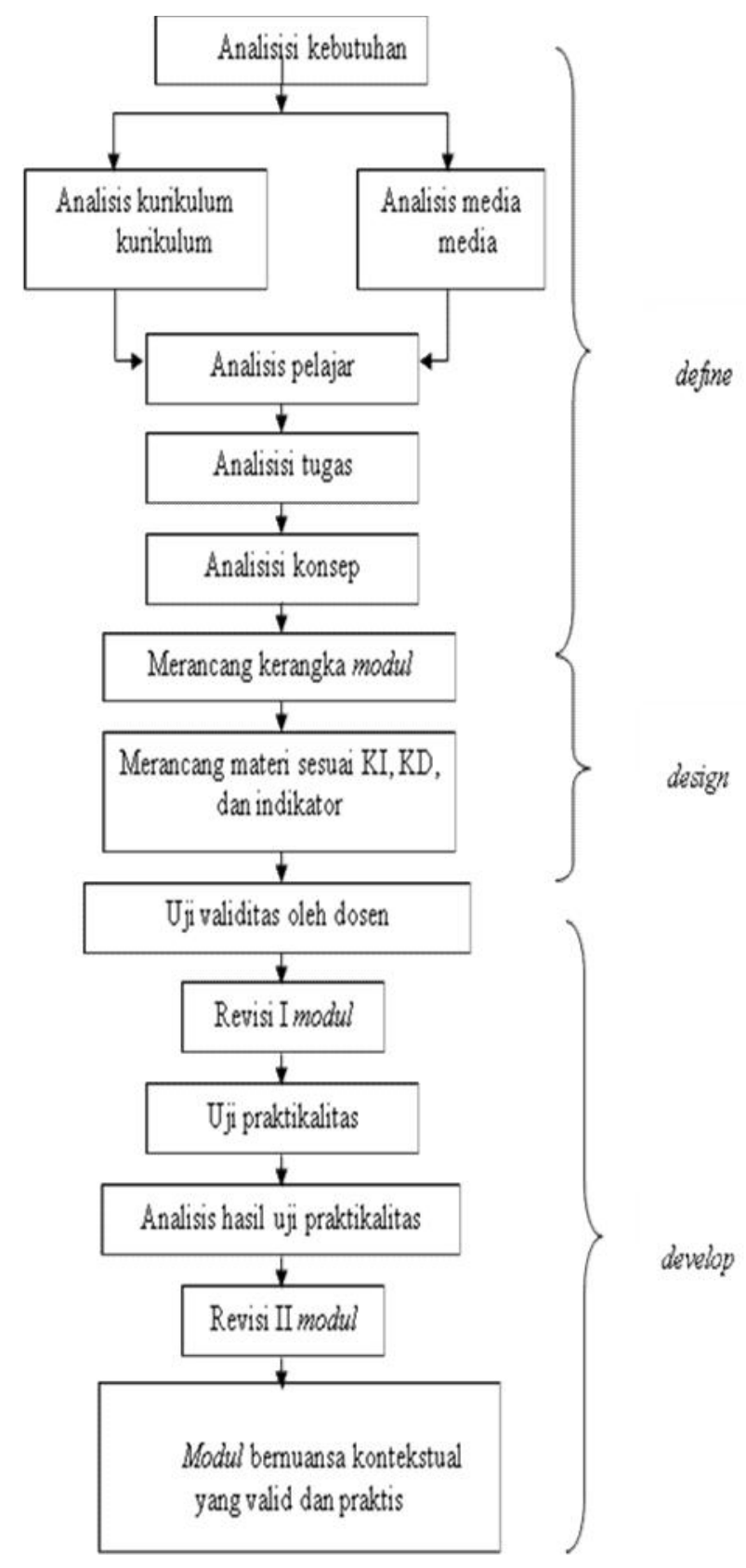

Gambar 1. Langkah-langkah pengembangan handout mengikuti model four-D-models

Teknik analisis data yang digunakan adalah data kualitatif dalam bentuk deskriptif yang mendeskripsikan validitas dan praktikalitas modul pembelajaran eksperimen fisika yang dikembangkan.

Analisis validitas modul berupa syarat didaktik, konstruksi, dan teknis berdasarkan lembar validasi dilakukan dengan beberapa langkah berikut : 
a. Memberikan skor jawaban dengan kriteria berdasarkan skala Likert ${ }^{[10]}$ sebagai berikut :

$4=$ sangat setuju

$3=$ setuju

$2=$ tidak setuju

1 = sangat tidak setuju

b. Menentukan skor tertinggi

Skor tertinggi $=$ jumlah validator $\mathrm{x}$ jumlah indikator $\mathrm{x}$ skor maksimum

c. Menentukan jumlah skor dari masingmasing validator dengan menjumlahkan semua skor yang diperoleh dari masing-masing indikator.

d. Penentuan nilai validitas dengan cara: Nilai validitas = $\frac{\text { jumlahskor yangdiperoleh }}{\text { jumlahskor tertinggi }} \times 100 \%$

e. Memberikan penilaian validitas dengan kriteria seperti yang dikemukakan oleh Purwanto
$90 \%-100 \%$
$=$ sangat valid
$80 \%-89 \%$
$=$ valid
$60 \%-79 \%$
$=$ cukup valid
$0 \%-59 \%$
$=$ tidak valid

Analisis praktikalitas modul bernuansa kontekstual Data uji praktikalitas penggunaan modul bernuansa kontekstual dianalisis dengan persentase (\%), menggunakan rumus berikut ini:

Nilai praktikalitas $=\frac{\text { Jumlahskor }}{\text { skormaksimum }} \mathrm{x}$ $100 \%$

Setelah persentase nilai praktikalitas diperoleh, dilakukan pengelompokan sesuai kriteria ${ }^{[10]}$ berikut ini.

$$
\begin{array}{ll}
90 \%-100 \% & =\text { sangat praktis } \\
80 \%-89 \% & =\text { praktis } \\
65 \%-79 \% & =\text { cukup praktis } \\
55 \%-64 \% & =\text { kurang praktis } \\
0 \%-54 \%=\text { tidak praktis }
\end{array}
$$

\section{HASIL DAN PEMBAHASAN}

1. Tahap Define (Pendefenisian)

a. Analisis Kebutuhan
Berdasarkan hasil pengamatan, didapati bahwa mahasiswa masih kesulitan memahami materi pelajaran fisika, salah satunya mata kuliah eksperimen fisika. Hal ini dikarenakan peserta didik belum mampu menghubungkan antara apa yang dipelajari dengan bagaimana pengetahuan itu digunakan. Di sisi lain, keberadaan bahan ajar yang digunakan siswa yang sulit dipahami dan tampilannya yang kurang menarik juga turut mengurangi minat siswa dalam belajar. Pernyataan ini berdasarkan pengamatan hasil wawancara dengan dosen fisika STKIP PGRI Sumatera Barat dan mahasiswa pendidikan fisika tahun masuk 2013, didapati bahwa bahan ajar yang digunakan belum dihubungkan dengan kehidupan sehari-hari.

b. Analisis Tugas

Analisis tugas lebih difokuskan pada perincian KI dan KD untuk mata kuliah eksperimen fisika yang dijabarkan menjadi indikator.

c. Analisis Konsep

Pada mata kuliah eksperimen fisika, konsep yang teridentifikasi adalah fungsi dan sistem kerja alat optik dan pemahanman terhadap konsep gelombang. Setelah terindentifikasi konsep-konsep pada mata kuliah eksperimen fisika, dihasilkanlah tujuan praktikum yang diacu dari indikator pembelajaran yang sesuai dengan tujuan dari pembelajaran eksperimen fisika.

2. Tahap Design (Perancangan)

Pengembangan modul ini dibuat sesuai dengan langkah-langkah pengembangan yang telah disusun. Modul ini dibuat dengan menggunakan aplikasi Microsoft Office Power Point dan Microsoft Word.

3. Tahap Develop (Pengembangan)

a. Validasi modul

Validasi modul kontekstual dilakukan oleh 5 orang validator yang terdiri dari dosen program studi 
pendidikan fisika dengan menggunakan angket validitas. Analisis hasil validitas secara ringkas ditampilkan pada Tabel 1.

Tabel 1. Hasil Validasi modul

Bernuansa Kontekstual

\begin{tabular}{|c|c|c|c|}
\hline No & $\begin{array}{c}\text { Komponen } \\
\text { Penilaian }\end{array}$ & $\begin{array}{c}\text { Nilai } \\
\text { Validitas }\end{array}$ & Kriteria \\
\hline 1 & $\begin{array}{c}\text { Kelayakan } \\
\text { Isi }\end{array}$ & $87 \%$ & Valid \\
\hline 2 & $\begin{array}{l}\text { Komponen } \\
\text { Kebahasaan }\end{array}$ & $86 \%$ & Valid \\
\hline 3 & $\begin{array}{l}\text { Komponen } \\
\text { Penyajian }\end{array}$ & $89,70 \%$ & $\begin{array}{c}\text { Sangat } \\
\text { Valid }\end{array}$ \\
\hline 4 & $\begin{array}{l}\text { Komponen } \\
\text { Kegrafikan }\end{array}$ & $85,00 \%$ & Valid \\
\hline \multicolumn{2}{|r|}{ Total } & $347,70 \%$ & \multirow{2}{*}{ Valid } \\
\hline \multicolumn{2}{|c|}{ Rata-rata } & $86,92 \%$ & \\
\hline
\end{tabular}

Keterangan:

Validator 1 : Dra. Hj. Husna, M.Si

Validator 2 : Silvi Trisna, M. Pd

Validator 3 : Helendra, S.Si, M.Si

Validator 4 : Mega Syani Anaperta, M. Pd

Validator 5 : Iing Rika Yanti, M. Pd

Hasil validasi pada Tabel 1 di atas menunjukkan nilai rata-rata sebesar $86,92 \%$ dengan kategori valid. Hal ini menunjukkan bahwa modul yang dikembangkan telah valid baik dari segi aspek kelayakan isi, kebahasaan, penyajian, maupun aspek kegrafikan sehingga dapat digunakan dalam pembelajaran.

Pada tahap validasi modul terdapat saransaran dari para validator yang menjadi dasar pertimbangan untuk melakukan revisi modul bernuansa kontekstual. Saransaran dan perbaikan dari validator dapat dilihat pada Tabel 2.
Tabel 2. Saran Validator dan Perbaikan terhadap modul Bernuansa Kontekstual dengan Tampilan Majalah

\begin{tabular}{|c|c|c|}
\hline $\begin{array}{l}\text { Val } \\
\text { idat } \\
\text { or }\end{array}$ & Saran & Perbaikan \\
\hline \multirow{3}{*}{1} & $\begin{array}{l}\text { a. Perlu } \\
\text { direvisi } \\
\text { penggunaan warna } \\
\text { huruf. }\end{array}$ & $\begin{array}{c}\text { Sudah } \\
\text { diperbaiki }\end{array}$ \\
\hline & $\begin{array}{l}\text { b. Perbaiki } \\
\text { konsep yang salah. }\end{array}$ & $\begin{array}{l}\text { Sudah } \\
\text { diperbaiki }\end{array}$ \\
\hline & $\begin{array}{l}\text { c. Perbaiki } \\
\text { tata letak gambar } \\
\text { dan lay out. }\end{array}$ & $\begin{array}{l}\text { Sudah } \\
\text { diperbaiki }\end{array}$ \\
\hline \multirow[b]{2}{*}{2} & $\begin{array}{l}\text { a. Kompetensi } \\
\text { inti belum ada }\end{array}$ & $\begin{array}{c}\text { Sudah } \\
\text { ditambahkan }\end{array}$ \\
\hline & $\begin{array}{l}\text { b. Daftar } \\
\text { Pustaka belum } \\
\text { ada. }\end{array}$ & $\begin{array}{c}\text { Sudah } \\
\text { ditambahkan }\end{array}$ \\
\hline \multirow{3}{*}{3} & $\begin{array}{l}\text { a. Ilustrasi } \\
\text { yang diberikan } \\
\text { harus relevan, } \\
\text { dapat dibaca } \\
\text { tulisannya dan } \\
\text { ukuran tidak } \\
\text { terlalu kecil. }\end{array}$ & $\begin{array}{c}\text { Sudah } \\
\text { diperbaiki }\end{array}$ \\
\hline & $\begin{array}{l}\text { b. Perbaiki } \\
\text { beberapa konten } \\
\text { materi yang masih } \\
\text { meragukan. }\end{array}$ & $\begin{array}{l}\text { Sudah } \\
\text { diperbaiki }\end{array}$ \\
\hline & $\begin{array}{l}\text { c. Gunakan } \\
\text { huruf yang lebih } \\
\text { formal. }\end{array}$ & $\begin{array}{l}\text { Sudah } \\
\text { diganti }\end{array}$ \\
\hline \multirow{2}{*}{4} & $\begin{array}{l}\text { a. Pertanyaan } \\
\text { pada akhir } \\
\text { modulditambahkan }\end{array}$ & $\begin{array}{c}\text { Sudah } \\
\text { ditambahkan }\end{array}$ \\
\hline & $\begin{array}{l}\text { b. Pertanyaan/ } \\
\text { latihan } \\
\text { divariasikan. }\end{array}$ & $\begin{array}{c}\text { Sudah } \\
\text { diperbaiki }\end{array}$ \\
\hline
\end{tabular}




\begin{tabular}{|l|l|c|}
\hline \multirow{5}{*}{5} & $\begin{array}{l}\text { a. Hilangkan } \\
\text { gambar dan } \\
\text { pewarnaan yang } \\
\text { tidak diperlukan. } \\
\text { b. Buatkan sumber } \\
\text { gambar. }\end{array}$ & dihilangkan \\
& Sudah \\
c. Perhatikan & ditambahkan \\
warna huruf. & Sudah \\
\hline
\end{tabular}

Sesuai saran dari validator, maka dilakukan revisi terhadap modul bernuansa kontekstual. Selanjutnya, modul bernuansa kontekstual yang telah direvisi diberikan kepada mahasiswa untuk dilakukan uji praktikalitas guna melihat tingkat kepraktisan dari modul yang dihasilkan.

b. Praktikalitas Handout

Uji praktikalitas modul bernuansa kontekstual dilakukan mahasiswa melalui angket praktikalitas. Data hasil angket praktikalitas.

Tabel 3. Hasil Praktikalitas modul bernuansa kontekstual mahasiswa STKIP PGRI Sumatera Barat.

\begin{tabular}{|c|l|l|l|}
\hline No & Aspek & $\begin{array}{l}\text { Rata-rata } \\
\text { Nilai } \\
\text { Praktikalitas }\end{array}$ & Kriteria \\
\hline 1 & $\begin{array}{l}\text { Kemudahan } \\
\text { Penggunaan }\end{array}$ & $86,51 \%$ & Praktis \\
\hline 2 & $\begin{array}{l}\text { Waktu } \\
\text { Pembelajaran }\end{array}$ & $81,00 \%$ & Praktis \\
\hline 3 & Manfaat & $82,76 \%$ & Praktis \\
\hline \multicolumn{2}{|l|}{ Total } & $250,27 \%$ & \\
\hline \multicolumn{2}{|l|}{ Rata-rata } & $83,42 \%$ & Praktis \\
\hline
\end{tabular}

Berdasarkan Tabel 3 dapat terlihat, bahwa nilai praktikalitas modul bernuansa kontekstual oleh mahasiswa STKIP PGRI Sumatera Barat adalah $83,42 \%$ dengan kriteria praktis. Hal ini menunjukkan, bahwa modul bernuansa kontekstual dengan tampilan majalah yang dikembangkan praktis digunakan oleh siswa dalam pembelajaran.

\section{Validitas Modul Bernuansa Kontekstual}

Analisis data dari angket validitas modul bernuansa kontekstual oleh validator yaitu dosen dan pengajar didasarkan pada empat aspek, yaitu kelayakan isi, kebahasaan, penyajian, dan kegrafikan. Hasil analisis data menunjukkan bahwa modul bernuansa kontekstual yang dikembangkan memperoleh nilai rata-rata validitas sebesar $86,92 \%$ dan memiliki kriteria valid.

Dari kelayakan isi, validator menilai 86,67\% dengan kriteria valid, yang berarti materi pada modul bernuansa kontekstual telah sesuai dengan kurikulum yang berlaku dan sesuai dengan tuntutan Kompetensi Inti (KI) dan Kompetensi Dasar (KD) yang dijabarkan menjadi indikator pembelajaran. Modul yang dikembangkan harus sesuai dengan kurikulum yang berlaku ${ }^{[4]}$. Kriteria valid untuk materi pada modul bernuansa kontekstual juga menunjukkan bahwa kebenaran substansi materi pada modul sudah baik. Kebenaran substansi ini perlu diperhatikan untuk menghindari kesalahan konsep dan pemahaman bagi mahasiswa.

Dari segi komponen kebahasan, modul bernuansa kontekstual yang dikembangkan memiliki nilai rata-rata $86,00 \%$ dengan kategori valid. Komponen kebahasaan ini berkenaan dengan penggunaan kalimat yang jelas sehingga tidak menimbulkan kerancuan sehingga mudah dimengerti oleh mahasiswa. Kalimat yang digunakan dalam modul harus sederhana, jelas, dan efektif agar pelajar mudah memahaminya ${ }^{[5]}$.

Ditinjau dari komponen penyajian, modul bernuansa kontekstual telah memuat indikator dan tujuan pembelajaran yang jelas. Materi pada modul bernuansa kontekstual juga telah disajikan secara lengkap sesuai dengan urutan pada indikator. Berdasarkan angket 
validitas terungkap bahwa komponen penyajian memiliki nilai rata-rata $89,70 \%$ dengan kriteria valid. Kejelasan indikator tujuan pembelajaran akan memudahkan mahasiswa belajar secara terarah. Dengan ini diharapkan dalam pembelajaran mahasiswa dapat mengikuti pelajaran dengan spesifik sesuai dengan indikator dan tujuan pembelajaran. $\quad$ Sudjana $^{[12]}$ mengungkapkan bahwa bahan pelajaran harus sesuai dengan urutan dan menunjang tercapainya tujuan pembelajaran.

$\begin{array}{ccc}\text { Dari } & \text { segi } & \text { komponen } \\ \text { kegrafikan, } & \text { modul } & \text { bernuansa }\end{array}$
kontekstual memiliki nilai validitas sebesar 85,00\% dengan kriteria valid. Hal ini menandakan bahwa desain modul yang dikembangkan sudah baik dan menarik meliputi bentuk dan ukuran huruf yang sesuai, gambar yang disajikan menarik dan relevan dengan materi, serta pemilihan warna yang sesuai dan menarik. Modul yang menarik akan mudah menarik perhatian mahasiswa untuk menggunakannya.

Secara keseluruhan nilai ratarata hasil uji validitas modul bernuansa kontekstual adalah 86,92\% dengan kriteria valid. Hal ini membuktikan bahwa modul yang dikembangkan telah memenuhi keempat aspek dalam uji validitas berdasarkan penilaian dari para validator sehingga modul ini dapat digunakan baik sebagai media pembelajaran atau sebagai sumber belajar.

\section{Praktikalitas Modul Bernuansa Kontekstual Uji}

praktikalitas modul bernuansa kontekstual dilakukan kepada mahasiswa. Dalam uji praktikalitas ini melibatkan 20 orang mahasiswa program studi pendidikan fisika
STKIP PGRI Sumatera Barat. Analisis hasil praktikalitas terhadap modul oleh mahasiswa memiliki nilai rata-rata $83,42 \%$ dengan kriteria praktis. Nilai praktis ini merupakan rata-rata dari 3 aspek dalam uji praktikalitas yaitu kemudahan penggunaan, efisiensi waktu pembelajaran, dan manfaat modul. mahasiswa menilai modul bernuansa kontekstual memiliki nilai $86,51 \%$ dengan kriteria praktis. Hal ini menunjukkan bahwa modul telah memiliki petunjuk penggunaan yang jelas sehingga mahasiswa mengetahui langkah-langkah yang harus dilaksanakan dalam praktikum dan mudah dalam menggunakan modul. Sesuai dengan yang diungkapkan Ahmadi \& Supriyono ${ }^{[6]}$ bahwa semakin mudah bahan pelajaran makin cepatlah orang dalam mempelajarinya.

Ditinjau dari segi efisiensi waktu pembelajaran, modul bernuansa kontekstual terbukti efisien bila digunakan dalam pembelajaran. Hal ini terlihat dari hasil praktikalitas oleh mahasiswa menilai $81.00 \%$ dengan kriteria praktis, Hal ini menunjukkan bahwa modul ini dapat digunakan oleh mahasiswa sebagai salah satu petunjuk dalam pelaksanaan praktikum eksperimen fisika.

$$
\text { Dari hasil angket }
$$
praktikalitas juga terlihat bahwa mahasiswa merasa senang belajar dengan modul bernuansa kontekstual. Selain itu, modul juga membuat mereka tertarik untuk membacanya karena tampilan modul yang dibuat semenarik mungkin seperti ketepatan pemilihan warna, huruf, dan ilustrasi. Dengan demikian, hal ini 
telah menjadi jawaban atas kendala yang dihadapi pengajar dimana mahasiswa kurang termotivasi dalam membaca dan modul sebelum praktikum. Nurseto mengemukakan bahwa media pembelajaran yang dirancang secara baik akan sangat membantu peserta didik mencapai tujuan pembelajaran.

Secara keseluruhan, hasil analisis validitas dan praktikalitas modul bernuansa kontekstual dinyatakan valid dan praktis. Dengan dihasilkannya modul ini dapat menjawab permasalahan kelemahan modul yang digunakan pengajar dan belum adanya modul bernuansa kontekstual untuk mata kuliah eksperimen fisika. Modul ini diharapkan dapat digunakan sebagai salah satu modul yang digunakan mahasiswa dan pengajar dalam pelaksanaan praktikum.

\section{KESIMPULAN}

Berdasarkan penelitian yang telah dilakukan, dapat disimpulkan bahwa:

1. Proses pengembangan modul bernuansa kontekstual dilakukan dengan menggunakan 3 tahap dari model 4D yaitu define, design, dan develop.

2. Hasil uji validitas diperoleh nilai validitas sebesar $86,92 \%$ dengan kriteria valid.

3. Hasil uji praktikalitas modul bernuansa kontekstual mahasiswa STKIP PGRI Sumatera Barat memiliki nilai rata-rata $83,42 \%$ dengan kriteria praktis.

\section{DAFTAR PUSTAKA}

Susilana, Rudi dan Cepi Riyana. 2009. Media Pembelajaran. Bandung: CV Wacana Prima.

Nurseto, Tejo. 2011. Membuat Media Pembelajaran yang Menarik. Online. Diakses 30 April 2013.
Depdiknas. 2008. Panduan Pengembangan Bahan Ajar. Jakarta: Kemendiknas.

Prastowo, Andi. 2011. Panduan Kreatif Membuat bahan ajar Inovatif. Yogyakarta: Diva Press.

Arsyad, Azhar. 2010. Media Pembelajaran. Jakarta: Raja Grafindo Persada.

Ahmadi, Abu dan Widodo Supriyono. 2004. Psikologi Belajar. Jakarta: Rineka Cipta.

Johnson, Elaine B. 2007. Contextual Teaching \& Learning: Menjadikan Kegiatan BelajarMengajar Mengasyikkan dan Bermakna. Bandung: Kaifa Learning.

Trianto. 2010. Mendesain Model Pembelajaran Inovatif Progresif. Jakarta: Kencana.

Riduwan. 2012. Pengantar Statistika Sosial. Bandung: Alfabeta.

Purwanto, M. Ngalim. 2009. PrinsipPrinsip dan Teknik Evaluasi Pengajaran. Bandung: PT. Remaja Rosdakarya.

Budiningsih, Asri. 2008. Belajar dan Pembelajaran. Jakarta : Rineka Cipta.

Sudjana, Nana. 2011. Dasar-dasar Proses Belajar Mengajar. Bandung: Sinar Baru Algensindo. 